\title{
SJoP
}

Book review: Reasons to be Graeae: a work in progress, edited by Jenny Sealey

\section{BEN FLETCHER-WATSON}

The Scottish Journal of Performance

Volume 5, Issue 2; September 2018

ISSN: 2054-1953 (Print) / ISSN: 2054-1961 (Online)

Publication details: http://www.scottishjournalofperformance.org

To cite this article: Fletcher-Watson, B., 2018. Book review: Reasons to be Graeae: a work in progress, edited by Jenny Sealey. Scottish Journal of Performance, 5(2): pp.103-106.

To link to this article: http://doi.org/10.14439/sjop.2018.0502.06

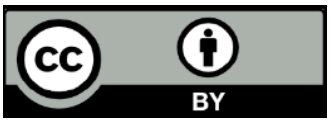

This work is licensed under a Creative Commons Attribution 4.0 International License. See

http://creativecommons.org/licenses/by/4.0/ for details. 


\section{Book review: Reasons to be Graeae: a work in progress, edited by Jenny Sealey}

BEN FLETCHER-WATSON

DOI: $10.14439 /$ sjop.2018.0502.06

Publication date: 30 September 2018

Reasons to be Graeae: a work in progress, edited by Jenny Sealey. London: Oberon Books Ltd, 2018; ISBN: 9781786823946 (£22.50)

Graeae, hailed by playwright Jack Thorne as 'Britain's National Theatre of Disability' (p.283), was founded in 1980. Over the subsequent 38 years, the company has moved from a hardscrabble existence based on project funding to its current position as the UK's leading disabled-led theatre company, touring internationally to great acclaim.

The story of Graeae is not simply one of incremental success leading to longevity. Since the start, the company has fought against patronising ableist attitudes, cynical accusations of positive discrimination, and wild shifts in policy towards people with disabilities. An arts officer for Hampshire County Council, an early funder, claimed in 1982 that 'not to be pro-Graeae is like being in favour of sin' (quoted in Saunders 2015, pp.102-3), but as founder Nabil Shaban notes, today 'the mainstream industry in all honesty does not want [disabled people] on their stages or on their screens' (p.32). Anger and activism drive the narrative throughout Reasons to be Graeae, layering stories of protest with anecdotes of performance. Indeed, the final pages of this book (remarkably, the first text to examine Graeae's history in detail) present the script for a verbatim piece, Sorry, which furiously attacks contemporary social policy 
such as the closure of the Independent Living Fund by the Conservative government in 2015.

Yet it is important to note that this anger has been a powerful force for change. In the words of Colette Conroy:

If we only regret the inflexible structures of theatre, its inaccessibility or its exclusiveness, we position ourselves as helpless functionaries of a pre-existing system. Studying the achievements of disabled cultural activists and artists over the last three decades is important in breaking through this deadlock (p.89).

The book offers readers the chance to do precisely that. Editor Jenny Sealey combines interviews, reviews, images, Top Ten lists, reflections and scripts into a fascinating history of disability-led arts. For example, several pieces note the role of critics, especially Lyn Gardner, as champions of diversity, with statements such as 'There are no limitations here, just glorious liberation' (p.273). Sealey and others go on to skewer certain media figures, including Rhoda Koenig for the Independent and Charles Spencer of the Daily Telegraph, whose attitudes are not as progressive. Adam Hemmings provides a superb brief primer on exclusionary language; he highlights the move from terms like 'handicapped' to the rise of the social model of disability, which begins with the premise that disability is directly caused by the ways in which society is organised, not by any one person's difference or impairment. Without the reclaiming of language by Graeae, it is difficult to imagine the emergence of companies such as Touretteshero, Birds of Paradise and Access All Areas.

Many contributors celebrate the close-knit structures of mutual support that have come to define the company. 
Nickie Miles-Wildin of Manchester's Royal Exchange Theatre declares, 'Graeae is family. It's support. It's people who get it and make work happen' (p.173). 'Family' is a refrain that runs throughout the book, perhaps echoing the original Graeae from Greek myth: three sisters sharing a single tooth and a single eye between them. As evidenced by Sealey's magisterial opening ceremony for the London Paralympic Games in 2012, created in just 14 months of part-time working, the company's training programmes have produced a new generation of $\mathrm{D} /$ deaf, disabled and non-disabled performers. Ex-soldier and amputee Jez Scarratt was taught to use the sway pole for open-air productions, and his chapter serves as a clarion call for their unique model of inclusion: 'I'll never be a big player in the life of cinema, theatre, or performance. But one thing I can assure you, I now love what I do' (p.241).

The book also serves to an extent as a valuable 'how-to' for the industry. For example, Richard Matthews, Head of Marketing and Development, sums up in four pages some basic rules for marketing to D/deaf and disabled audiences that most venues still have not managed to achieve. The company's established blend of British Sign Language, captioning and audio description remains among the greatest contributions to accessibility in the arts of the past 30 years.

There are a few omissions, such as the rise of the neurodiversity movement alongside increased opportunities for training at UK conservatoires and drama schools. Ramps on the Moon, an ongoing movement seeking to revolutionise inclusion of $\mathrm{D} /$ deaf and disabled people within the culture sector, would not have happened without the leadership of Sealey and others from Graeae, but there are only fleeting references to the project here. However, these are minor quibbles. This highly readable and rich text will be of interest to a wide readership, and could as easily 
find its place on theatregoers' bookshelves as on theatre studies reading lists. Contributors from the long history of the company, including actors, administrators, academics and allies, present a tapestry of tales that rightly place Graeae at the very centre of British theatre. I can only echo the words of voice coach Christopher Holt:

...it is for theatre's sake that this company exists. To deliver and provoke art that questions the mainstream, the WASP, the heteronormative, the humdrum. We are the outsiders and the queers and we have power (p.158).

\section{References}

Saunders, G., ed., 2015. British theatre companies: 1980-1994. Joint Stock, Gay Sweatshop, Complicite, Forced Entertainment, Women's Theatre Group, Talawa. London: Bloomsbury Methuen Drama.

\section{About the review author}

DR BEN FLETCHER-WATSON manages the Institute for Advanced Studies in the Humanities at the University of Edinburgh. His research explores performance for non-traditional audiences, including babies, people with dementia and spectators on the autism spectrum. He was a founding editor of the Scottish Journal of Performance. 